\title{
How to teach Entrepreneurship: Results of the new teaching methodology in the Course „Creating Innovative Companies” with graduate students
}

\author{
Juan J. Jimenez-Moreno*
}

\begin{abstract}
In this paper we described the course "Creating innovative companies" (6 ECTS credits) and the entrepreneurial profile of the students. The course is taught in the fourth year of the Business Administration and Management Degree, at the Faculty of Economics and Business, in the University of Castilla-La Mancha (Spain). We deal with its justification and its place in the degree, skills and objectives, program and content, activities (individual practical work, optional seminars, preparation and presentation of a business plan) and the teaching methodology, which emphasizes autonomous individual and group work, scheduled work sessions (entrepreneurship, entrepreneur, business ideas, business plan), the evaluation criteria and grading. The socio-demographic profile of the students is also presented in terms of gender; age; nationality (with a high representation of foreign students); family background; student entrepreneurial self-perception; desirability, feasibility, and intention of creating a business; and student perception of risk. The questionnaire used is based on models by Shapero (1982), Ajzen (1987) and Krueger (2007). We also presented students' evaluation of the methodology (preparation of activities, the methodology itself, the usefulness of learning activities, group work) and of the course (usefulness, interest, content, materials, assessment criteria, professors, etc.) and the achieved academic results. The findings will help us improve the adjustment of the methodology used, generating good practices that will result in a more efficient achievement of the course objectives. On the other hand, and more importantly, we would allow for knowing the impact of the training on student entrepreneurial intentions.
\end{abstract}

Keywords: teaching methodology, entrepreneurship, graduate students.

Submitted: 15.06.2014 | Accepted: 05.09.2014

\section{Jak uczyć przedsiębiorczości - wyniki nowej metodyki nauczania przedmiotu „Tworzenie innowacyjnych firm" wśród studentów}

$W$ artykule opisano przedmiot zatytułowany „Tworzenie innowacyjnych firm” (6 punktów ECTS) oraz profil przedsiębiorczy studentów. Przedmiot wyktadany jest na czwartym roku studiów w zakresie administracji i zarzadzania przedsiębiorstwami na Wydziale Ekonomii i Biznesu na Uniwersytecie Kastylii-La Manchy (Hiszpania). Omówiono jego uzasadnienie $i$ umiejscowienie $w$ programie studiów, umiejętności $i$ cele, program i treść, zajęcia (indywidualne zajęcia praktyczne, seminaria fakultatywne, przygotowanie i prezentacja biznesplanu) oraz metodykę nauczania, która kładzie nacisk na niezależna pracę indywidualna i grupowa, zaplanowane sesje zajęciowe (przedsiębiorczość, przedsiębiorca, pomysty na biznes, biznesplan), a także kryteria i system oceniania. Przedstawiono również profil spoteczno-demograficzny studentów w kategoriach ptci, wieku, narodowości (duża reprezentacja studentów

\footnotetext{
* Juan J. Jimenez-Moreno - Faculty of Economics and Business, University of Castilla-La Mancha (Spain).

Corresponding author at: Juan.Jimenez@uclm.es.
} 
zagranicznych), sytuacji rodzinnej, samooceny studenta pod względem przedsiębiorczości, celowości, wykonalności i intencji utworzenia przedsiębiorstwa oraz postrzegania ryzyka przez studenta. Wykorzystany kwestionariusz opiera się na modelach, które opracowali Shapero (1982), Ajzen (1987) i Krueger (2007). Zaprezentowano także ocenę metodyki (przygotowanie zajęć, sama metodyka, użyteczność zajęć edukacyjnych, praca w grupie) i przedmiotu (użyteczność, atrakcyjność, treść, materiaty, kryteria oceny, wykładowcy itd.) przez studentów oraz uzyskane prze nich wyniki. Ustalenia te pomoga lepiej dostosować metodyke, dzieki opracowaniu dobrych praktyk, które pozwola na bardziej efektywna realizację celów przedmiotu. Co ważniejsze, umożliwia one poznanie wplywu szkoleń na intencje przedsiębiorcze studentów.

Słowa kluczowe: metodyka nauczania, przedsiębiorczość, studenci.

Nadesłany: 15.06.2014 | Zaakceptowany do druku: 05.09.2014

JEL: A22, L26

\section{Introduction}

The new European Higher Education Area (EHEA), emerging from the Bologna Declaration (1999), represents an opportunity to introduce the changes that the educational system needs. In the case of Spain, this new framework arises from the Organic Law for Universities (2001) and its subsequent reform (2007), as well as from the measures taken for the elaboration of the new Graduate and Masters' degrees. In this new context, knowledge is framed around basic skills: knowing, know-how, knowing how to be and knowing how to work with others. Training should be multipurpose and permanent and one should learn to learn (self-learning). All of this obviously meant structural changes and the necessary adaptation to teaching methodologies in keeping with the new perspectives, based on the acquisition of knowledge, skills, and abilities. These changes represent an opportunity to introduce new pedagogical methods and to carry out the improvements that the system needed. The economic crisis and the consequent budget cutback that public universities are experiencing have restricted the majority of the advantages that the new model offered. Nevertheless, some European universities and many Spanish universities did, in fact, consider introducing or maintaining training in entrepreneurship and promoting an entrepreneurial culture among their students in order to achieve an important qualitative change among their graduates.

In this paper, we present some of the results of the application of this new teaching methodology employed in the course
"Creation of Innovative Companies", in the Business Administration and Management degree at the University of CastillaLa Mancha (Spain).

\section{The new european model}

In the Lisbon strategy (2000), the European Union considered a series of goals - innovation, competitiveness, and growth - that, in the medium term, would allow improved socio-economic positioning of the European Community in the international context, in response to the changes produced as a consequence of globalization, among other factors. Obviously, one of the instruments for achieving that change in the economic-productive system is to promote, at the various levels of the educational system, a change of values among young Europeans, young citizens who will be the future human resources, professionals, businesspeople, researchers, and politicians.

Regardless of whether the solution to the current economic-financial crisis produces a change in the market economy model or not, such as has been conceived up until now, it is evident that businesses continue to be the most efficient instrument in the system for the creation of wealth and employment. The economic system will be more dynamic and efficient if there are more competition and more innovation. Competition and innovation will be favored if there are more people with initiative and sufficient abilities to create new companies.

The question that arises facing this panorama is how to strengthen more and 
better entrepreneurial initiatives. The answer is evident: by promoting a strong entrepreneurial culture in the European society, and to achieve the enduring social permanence of these values, it seems obvious that the best medium for extending them is the educational system. In fact, the European Union already explicitly takes this approach in some references that will mark its action in the years to come ${ }^{1}$. Anticipating these proposals, some European universities, committed to the process of Europeanization, have assumed a social role: contribution to the socio-economic development of their region. These universities are aware of this need and they are promoting an entrepreneurial culture among students and they are offering training in this regard, as a service to their university community, but with a significant leverage effect on the whole society.

\section{The university background}

Castilla-La Mancha University (UCLM) was created in 1982, but did not commence its teaching activities until the 1985-1986 academic year. Later, the Faculty of Economics and Business Studies was created, commencing its course in the 1987-1988 academic year, offering Bachelor's degrees in Economics and in Business Studies. The University of Castilla-La Mancha was a pioneer among Spanish universities in offering training in Entrepreneurship in the format of an elective course in the curriculum. In 1987, the first curriculum of the Bachelor of Business Administration offered an elective course called "Managing SMEs" for 1.5 credits, which originally included some implicit content in Entrepreneurship. In 1992, following the reform of the curriculum, the course became a new elective "Management of SMEs" for 4.5 credits, in which the first contents in Entrepreneurship appeared explicitly in the academic year of 1992-1993. Gradually these contents were refined and expanded to become proportionally the majority of the subject matter, although for administrative reasons the name of the course remained the same. In 2003, with the change of the Bachelor in Business to the Degree in Business Administration and Management, the course of "Entrepreneurship" for 4.5 credits was offered at the Faculty of Economics and Business in Albacete, a course that was replicated in other faculties which taught the same degree at other UCLM campuses (Ciudad Real, Cuenca and Toledo). In 2009, in the process of adaptation to the EHEA and implementation of the new Degree and Master's, a favorable report was obtained from the National Agency for Quality Assessment and Accreditation (ANECA) for the new Degree in Business Administration and Management at the University of Castilla-La Mancha, which was introduced in the 2009-2010 academic year, beginning with the first year subjects. This Degree is only for the Faculty of Economics and Business at the Campus of Albacete. The course "Creating Innovative Companies" was featured and taught for the first time in the academic year 2012-2013.

\section{The course}

In September 2012, the new course, "Creating Innovative Business", was offered as an elective for 6 credits (ECTS) to students of Business Administration and Management (GADE) for the "Mention" in "SME Management", at the Faculty of Economics and Business, at the Albacete Campus. According to the established program, it is taught during the first semester of the 4th year (September to December of each academic year). This course is the result of the transformation, adaptation and extension of the previous one, derived from the process representing the EHEA convergence, so that the transition to the new course for the Degree has been simple. The Teaching Guide includes competencies, outcomes, content, activities, methodology, evaluation criteria, assessment, and programming resources, gathering the best practices achieved in years of teaching experience.

The purpose of the course is to train students in the knowledge of the process of starting a business, developing a range of skills from exercising the role of an entrepreneur, to developing a business plan, through the ability to generate innovative business ideas. It is not intended, however, that students explicitly create their own business immediately, but that they acquire business skills and experience and know the conditions and process to create a company, which, obviously, can help later if they have that intention. However, UCLM offers other services (e.g. UCLM-Enter- 
prising Program, Vice-President of Corporate Relations and Transfer) with outreach and training activities for its students to create specialized companies.

\subsection{Pre-requisites and justification of the curriculum}

Given the course profile, specific prerequisites are not necessary. However, basic knowledge of Accounting, Marketing, Business, Finance and Management would be useful. Also, it is advisable to have transversal abilities to search for information from various sources, capabilities of analysis and synthesis, teamwork, the ability to make decisions, oral and written communication skills and the ability to use ICT. Initiative, an enterprising spirit and creativity would also be helpful although they are not pre-requisites either.

The subject is justified by the following arguments in the Curriculum for the Degree in Business Administration and Management: businesses are the engine of the system's economic development to generate wealth and employment. Besides, our socio-economic system is based on the market economy model covered in Article 38 of the Spanish Constitution. The elements of the market economy model, according Schumpeter's concept, are private property, the market, competition and profit, and emphasis on the entrepreneur (innovator). The businesses of any modern society are a dynamic reality in which the birth and death of firms make the model more efficient to the society.

The majority of our future graduates will work professionally in companies or for companies, in very small sized businesses (SMEs) where the role of the businessperson-founder is determinant. On the other hand, the entrepreneurship of large enterprises plays a very important role in invigorating the economic system by incorporating innovations with great socio-economic repercussions through Research, Development and Innovation (RDI) processes. Some of our graduates will be public servants who will perform tasks at posts related to SMBs. Finally, a limited but very important part of our graduates $(5 \%)$ contemplate the creation of their own business as a desirable alternative to working for somebody else.

Therefore, logically, our students should know the process of business creation, its artifices, the process for generating innovative business ideas, starting a business and managing it efficiently during the first several years of its life to ensure its survival and development.

\subsection{Skills and objetives}

The course contributes to the express achievement of the following skills:

Specific skills:

E1) Managing and administering a business or organization, understanding its competitive and institutional situation and identifying its weaknesses and strengths

E2) Administering the enterprising spirit, the ability to adapt to changes and creativity in all functional areas of the business or organization

E4) Ability to integrate oneself in any functional area of a company or organization to perform any task assigned

E6) Capability of general administration, technical direction and management of research projects, development and innovation in any type of business or organization

Generic skills:

G1) A high degree of independence in selfdirection and autonomy in continuing education to permit the development of the ability to learn what is necessary for undertaking subsequent study

G3) Development of oral and written communication skills for preparing reports, research projects, business projects, and the ability to defend oneself before commissions or collectives whether specialized in more than one language or not, perceiving pertinent evidence and interpreting it adequately

G5) Capability of teamwork: to be a leader, to direct, plan and supervise multidisciplinary and multicultural teams in the business' national and international environment and its respective departments in order to obtain beneficial synergies for the entity.

Objectives or expected results:

O1) The student will be able to determine the role of new innovative businesses in the dynamism of the economic system and to discover the socio-economic setting where business creation processes are developed. The skills that will be obtained are: E1 and G1. 
O2) The student will be able to identify the characteristics of enterprising individuals in their socio-demographic as well as psychological and motivational dimensions. The student will also be able to identify several enterprising profiles. The skills that will be obtained are: E1, E2, and G1.

O3) The student will be able to activate his/her own creative capacity, generate and search for business ideas and evaluate his/her own innovative potential. The skills that will be obtained are: E2 and G3.

O4) The student will be able to prepare a technically, economically and socially viable business plan. He/she will be able to determine which resources are necessary and will be able to establish the business' promotional strategy.
The skills that will be obtained are: E1, E4, E6, G3 and G4.

\subsection{Program and contents}

The course syllabus is structured into four parts. The first part addresses the environment and dynamism of the business system. The second part deals with the socio-demographic and psychological profile of entrepreneurial persons and their reason for starting a business. In the third part the process of generation of ideas is analyzed, creativity techniques are used, innovative ideas are generated and their validity as business ideas is evaluated. In the fourth part a business plan is prepared, touching on its technical, economic and social viability. A detailed syllabus of the course and the contents of each part are shown in Table 1.

Table 1. Syllabus: the contents of the course

\begin{tabular}{|c|c|}
\hline Topics & Content \\
\hline $\begin{array}{l}\text { 1. Business creation? } \\
\text { - The role of businesses in the economic sys- } \\
\text { tem } \\
\text { - Enterprises } \\
\text { - Birth and death of businesses } \\
\text { - The environment of the business creation } \\
\text { process }\end{array}$ & $\begin{array}{l}\text { - Recognition of the business activity in the mar- } \\
\text { ket economy } \\
\text { - Description of the European, national, regional } \\
\text { and local businesses } \\
\text { - Dynamic dimension of the businesses } \\
\text { - Contextualization of the business creation } \\
\text { process }\end{array}$ \\
\hline $\begin{array}{l}\text { 2. The enterprising businessperson } \\
\text { - What profile does he/she have? } \\
\text { - What motivates him/her to start? } \\
\text { - What abilities are necessary? } \\
\text { - What characterizes an enterprising individ- } \\
\text { ual? }\end{array}$ & $\begin{array}{l}\text { - Personification of the process } \\
\text { - Identification of enterprising individuals } \\
\text { - Characterization of potential businesspersons }\end{array}$ \\
\hline $\begin{array}{l}\text { 3. The innovative idea: a business opportunity } \\
\text { - How to get an innovative idea? } \\
\text { - How to evaluate innovative ideas? } \\
\text { - What are the keys for selecting an idea? } \\
\text { - What to do to maintain the advantages of an } \\
\text { innovation? }\end{array}$ & $\begin{array}{l}\text { - Creative capacity as a source of business ideas } \\
\text { - From a creative idea to economic innovation } \\
\text { - The evaluation process for potentially innova- } \\
\text { tive ideas }\end{array}$ \\
\hline $\begin{array}{l}\text { 4. The business plan } \\
\text { - What is a business plan and what is it for? } \\
\text { - How is a business plan made? } \\
\text { - Is my idea technically and economically } \\
\text { viable? } \\
\text { - How to direct the new business strategi- } \\
\text { cally? }\end{array}$ & $\begin{array}{l}\text { - From an innovative idea to a business project } \\
\text { - The new business' genetic code } \\
\text { - Strategic analysis of the new business } \\
\text { - Strategic planning for the success of the new } \\
\text { business }\end{array}$ \\
\hline
\end{tabular}




\section{Activities and teaching methodology}

The students will perform practical activities based on self-learning and participatory learning in which the various contents of the program will be worked on through classroom sessions and through the Virtual Campus, through the performance of independent individual tasks, cooperative learning, supervised and group work in the classroom and in tutoring sessions. The activities and the teaching methodology are presented in Table 2.

\section{A. Thematic sections}

in the first session of the course the mission, core objectives, methodology (activities, assessment and evaluation) and available resources are explained. The resources required for the preparation of the course are on the UCLM Virtual Campus platform. The platform is also used for communication with students (internal mail, forum, news, announcements, etc.), for handing in papers and for monitoring controlled practical training and scheduled activities.

\section{Section 1: Business creation}

The purpose of this section is to make the student aware of the importance of the business activity in the operation, maintenance and invigoration of the market economy system and how the business whole represents a changing reality due to the continual entry (birth) and exit (death) of businesses. Subsequently he/she will be able to focus his/her attention on the reason for the creation of a business and the context where this happens.

This Section starts with a classroom session led by the professor (participatory lecture) on the market economy system and the role of business. Since students have previous knowledge from basic subjects, the new knowledge is related to what they already know through direct questions to the students. Practical tasks TP1 and TP2 are proposed (autonomous individual work):

- Search for information about the Spanish and European market that proves the existence of the market economy system.

- Search for information on the European, Spanish, and regional businesses. Arrange the information according to business dimensions, sectors, juridical persons, employment, business sales, age and location. Relate the number of businesses to the population. Reach conclusions on the business configuration.

- Search for information about the number of businesses created and businesses that stopped their activity in recent years by country, autonomous community and province. Weigh this data against the number of inhabitants and the number of existing businesses.

Table 2. Activities and Teaching Methodology

\begin{tabular}{|l|l|}
\hline \multicolumn{1}{|c|}{ Activities } & \multicolumn{1}{c|}{ Methodology } \\
\hline Theoretical-practical classes & Participatory magisterial classes \\
\hline Weekly practical tasks & Independent individual tasks through student tutorials \\
\hline Voluntary tasks & Independent individual tasks through student tutorials \\
\hline Optional seminars & $\begin{array}{l}\text { Cooperative learning } \\
\text { Tutored group work }\end{array}$ \\
\hline Lectures & Participatory magisterial classes \\
\hline Preparation of a business plan & $\begin{array}{l}\text { Independent individual or group work } \\
\text { Tutored individual or group work } \\
\text { Tutorials }\end{array}$ \\
\hline $\begin{array}{l}\text { Preparation of the presentation of the } \\
\text { business plan }\end{array}$ & Independent individual or group work \\
\hline Presentation of the business plan & Explanation and discussion \\
\hline
\end{tabular}

Wydział Zarządzania UW ～DOI 10.7172/1733-9758.2014.17.4 
Having completed the delivery of tasks, students discussed in class the main conclusions they drew (supervised group work in class).

When the students have finished this section, they should have achieved goal number $\mathrm{O} 1$ and perfected aptitudes E1 and $\mathrm{G} 1$.

\section{Section 2: The enterprising businessperson}

The purpose of this block is to personify the process of business creation so that the object of attention is not the new business but rather the person who promotes it (its founder). This leads to trying to identify that person: his/her socio-demographic profile (age, gender, education, etc.); psychological profile (locus); and motivation for starting a business (need, desire, social purpose).

This process is led by the professor (participatory lecture), asking a series of questions that must be answered in practical tasks TP3 and TP4. Subsequently it is discussed in a classroom session either on the entrepreneurship of individuals and their success or otherwise on the creation of a business (supervised group work in class). The next milestone will be to define the term "entrepreneur" from an economic perspective. The professor leads the session (participatory lecture), commenting on other perspectives and presenting practical task TP5. The main contributions are subsequently discussed in a classroom session (supervised group work in class). This section ends with making direct contact with a new businessperson in an interview arranged and conducted by the student (independent individual task) to verify whether current conclusions (profile, motivation) are corroborated. Practical task TP6 will be proposed. Then key findings from the interviews are discussed in a classroom session (tutorial group work in class).

When this section is finished, the student should have achieved objective $\mathrm{O} 2$ and perfected aptitudes E1, E2 and G1.

\section{Section 3: The idea of an innovative business}

The aim of this section is for the student to assume the role of an enterprising person generating and/or searching for potential business ideas, by putting his/her creative skill into practice. Then the (eco- nomic) innovative potential of the ideas will be analyzed.

The process is held in a classroom session by the professor (participatory lecture), raising issues that will be addressed in practical tasks TP7 and TP8. Students describe their own business idea which is new, useful and practical. They indicate the origin (source) of the process. They evaluate whether it would be useful to other people. They list 10 new products or services that have appeared in the last 5 years, indicating their originality and competitiveness, advantages, improvements or features which they cover that did not exist or were not attended to previously. Subsequently, based on the examples provided by the students, reflection is made in a classroom session on the sources of business ideas, the relationship between utility and business idea (innovation) and between competitiveness and originality (supervised group work in the classroom). The causes of the failure of new companies are addressed in reference to the results of practical task TP9 (supervised group work in classrooms). Students must search for businesses that are considered about to fail in the short or medium term. They identify them and give a reasoned explanation for the cause of their failure.

During the development of this block, a visit is projected to attend some of the events that promote the entrepreneurial culture and values, programmed by several institutions and public entities. It is a voluntary activity and registration is required. Given its nature, places are limited (50). On the return trip, the most interesting aspects of the visit are discussed.

When this section is finished, the student should have achieved objective O3 and perfected aptitudes E2 and G3.

\section{Section 4: The business plan}

The aim of this section is for the student to prepare a technically, economically and socially viable business plan, to determine what resources are necessary for starting the business and to set a strategy for launching the business.

There is a specific protocol for working out the business plan where basic contents are fixed, as are formal and temporal conditions for carrying it out, handing it 
in and presenting it in class. That protocol is completed based on frequent doubts and questions and with reference examples from the best business plans from previous years.

Students are free to decide whether to prepare the business plan individually or in a group. The methodology for preparing this paper is based on a model adapted to cooperative learning for the group option and self-directed, independent learning for the individual option. In the case of the group option, students are free to form work groups under the sole condition that the group cannot have more than 4 members ( 3 members being advisable).

Following the established protocol, students must communicate the name of the future business, the business idea and the members who will carry out the work through the Virtual Campus. Once this communication is sent, the chosen business ideas will be made public and the timetable will be established for delivery of the paper through the Virtual Campus and its presentation in the classroom. Obligatoryattendance tutorials will be programmed for each project, besides attendance at tutorials on demand and online consultations. Students will work out their business plan (independent individual or group work, tutored group work in the classroom, tutorials) by following the established guidelines and any of the ad hoc proposed models.

In order to improve the student's skill of critical analysis regarding his/her own business plan, the TP10 practical task will be proposed. It consists in analyzing a reference business plan (selected from among papers from previous years), with the purpose of identifying weaknesses and strengths, threats and opportunities (WSTO).

Two lectures, L1 and L2, will be scheduled during the development of this section. Young businesspersons of various profiles and ambits will participate and explain their experience in creating their own businesses.

For the presentation of the business plan, students will explain a summary of their business plan in class. (They should have sent that presentation beforehand through the Virtual Campus.) They will emphasize the most relevant aspects of the originality of the business idea, the main source of innovation, strategic competitiveness and project viability. The time available for explaining each plan is 15 minutes minimum and 20 maximum, freely administrated. When the presentation is finished, the professor and the students in attendance can ask questions. At the end of each session, the professor will summarize the most important and outstanding aspects of each presentation.

When this section is finished, the student should have achieved objective $\mathrm{O} 4$ and perfected aptitudes E1, E4, E6, G3 and G4.

\section{b. Timetable}

The course is taught over a period of 15 weeks with 2 sessions per week, each session lasting 1 hour and 30 minutes. The distribution of time for 6 ECTS credits equivalent to 150 hours of student work is as follows: $40 \%$ is used for various activities in the classroom and $60 \%$ for individual or group tasks, preparation activities, study and self-learning. The distribution of sessions and individual tasks is shown in Table 3.

Table 3. Distribution of sessions and individual tasks

\begin{tabular}{|l|l|}
\hline \multicolumn{1}{|c|}{ Topic } & \multicolumn{1}{c|}{ Time spent } \\
\hline Presentation & 1 session \\
\hline 1. Enterprise creation? & 3 sessions and 2 individual papers \\
\hline 2. The enterprising businessperson & 6 sessions and 4 individual papers \\
\hline 3. The innovative business & 6 sessions and 3 individual papers \\
\hline 4. The business plan & 8 sessions and 1 individual paper \\
\hline Presentation of business plans & 6 sessions \\
\hline
\end{tabular}

Wydział Zarządzania UW ～DOI 10.7172/1733-9758.2014.17.4 
Table 4. Distribution of grading criteria

\begin{tabular}{|l|c|c|c|c|}
\hline Individual tasks & $40 \%$ & \multirow{2}{*}{ OR (optional) } & Final exam & \multirow{2}{*}{$50 \%$} \\
\cline { 1 - 2 } Class participation & $10 \%$ & & \\
\cline { 1 - 2 } (Voluntary tasks) & $(10 \%)$ & & & \\
\hline And (required) & & & & $40 \%$ \\
\hline Creation of a business plan & & & & $10 \%$ \\
\hline
\end{tabular}

\section{c. Grading system}

the grade for the course is established considering each student's active participation in the various activities taking place face to face and in virtual meetings $(10 \%)$ in carrying out practical activities and individual scheduled tasks (40\%), in the development of a business plan (40\%) and in the public oral presentation and defense of the business plan (10\%) developed individually or in groups. A summary can be seen in Table 4.

\section{The students}

There were 50 students registered in the course "Creation of Innovative Companies" in the academic year 2012-20133, of which $66 \%$ were female students and $34 \%$ male; $64 \%$ were nationals, mainly from the same region of Castilla-La Mancha, and 36\% were foreigners, of which $66.7 \%$ came from different European countries (in this case from Belgium, Italy, Poland, and Romania) under Erasmus programs, and the remaining 33.3\% from Latin America under bilateral agreements between universities (Brazil and Mexico). The largest group was formed by Spanish female students (42\%), followed by foreign female students (24\%), Spanish male students (22\%), and foreign male students $(12 \%)$. See Table 5.

Table 5. Percentage distribution of students by nationality and gender

\begin{tabular}{|c|c|c|c|c|}
\hline \multirow{3}{*}{\multicolumn{3}{|c|}{$\begin{array}{l}\text { Students by nationality and } \\
\text { gender }\end{array}$}} & \multicolumn{2}{|c|}{ Gender } \\
\hline & & & \multirow{2}{*}{$\begin{array}{l}\text { Male } \\
34 \%\end{array}$} & \multirow{2}{*}{$\frac{\text { Female }}{66 \%}$} \\
\hline & & & & \\
\hline \multirow{2}{*}{ Nationality } & Spanish & $64 \%$ & $22 \%$ & $42 \%$ \\
\hline & Foreign & $36 \%$ & $12 \%$ & $24 \%$ \\
\hline
\end{tabular}

At the beginning of the course, during the presentation session, information is gathered on the students' profile (gender, age, and nationality). They are asked, moreover, about their motive for registering: whether they consider themselves enterprising people, whether they have ever had a business idea, whether they have ever thought about the possibility of creating their own business, whether they consider the idea of creating their own business attractive and feasible, whether there is a probability of creating their own business within the next 5 years, whether they think that creating a company is risky, what they think their career development will be, and whether there are any business references in their family or social circles.

The average age of the students was 21.94 years. See Table 6. The youngest group was formed by female Spanish students (21.2 years old) and the oldest by male Spanish students (23.7 years old).

Table 6. Average age of students by nationality and gender

\begin{tabular}{|c|c|c|c|c|}
\hline \multirow{3}{*}{\multicolumn{3}{|c|}{$\begin{array}{l}\text { Students by nationality and } \\
\text { gender }\end{array}$}} & \multicolumn{2}{|c|}{ Gender } \\
\hline & & & \multirow{2}{*}{$\begin{array}{c}\text { Male } \\
22.7\end{array}$} & \multirow{2}{*}{$\begin{array}{c}\text { Female } \\
21.5\end{array}$} \\
\hline & & & & \\
\hline \multirow{2}{*}{ Nationality } & Spanish & 22.0 & 23.7 & 21.2 \\
\hline & Foreign & 21.8 & 21.6 & 22.0 \\
\hline
\end{tabular}

By means of an open-ended question, they were asked to consider what their main motive was for choosing the course. The majority $(54.7 \%)$ responded that it was out of interest in the topic, followed by the intention to have their own business or 
Table 7. Percentage distribution by reason for choosing the course

\begin{tabular}{|c|c|c|c|c|c|}
\hline Items & Total & Male & Female & Spanish & Foreign \\
\hline Not in my University & $1.8 \%$ & $1.8 \%$ & & & $1.8 \%$ \\
\hline Best schedule & $1.9 \%$ & & $1.9 \%$ & & $1.9 \%$ \\
\hline Recommendation & $3.7 \%$ & $1.8 \%$ & $1.9 \%$ & $3.7 \%$ & \\
\hline To be an entrepreneur & $20.7 \%$ & $7.5 \%$ & $13.2 \%$ & $13.2 \%$ & $7.5 \%$ \\
\hline Subjects package & $16.9 \%$ & $3.7 \%$ & $13.2 \%$ & $16.9 \%$ & \\
\hline Interest / I like & $54.7 \%$ & $16.9 \%$ & $37.7 \%$ & $39.6 \%$ & $15.1 \%$ \\
\hline Total: & $100.0 \%$ & $32.1 \%$ & $67.9 \%$ & $73.6 \%$ & $26.4 \%$ \\
\hline
\end{tabular}

create their own company $(20.7 \%)$. Other reasons were because it forms part of the package of courses for the major in "Management of SMEs" (16.9\%), because of a recommendation $(3.7 \%)$, because they are not in their own university of origin $(1.9 \%)$, and because of the class schedule $(1.8 \%)$. See Table 7 for the results.

Regarding whether they consider themselves enterprising, they were asked a 10-point Likert scale question (1: no, not at all; 10: yes, totally). The average value is 6.57 out of 10 , with no big differences when considering the groups in terms of gender and nationality (see
Table 8). The majority (60\%) considered themselves "quite" enterprising, followed by "normal" (22.9\%), "not very" $(11.4 \%)$, and "totally" enterprising $(5.7 \%)$ : Table 9.

Concerning whether they have at some point had a business idea or have ever considered the possibility of creating their own company, both questions were asked by using a dichotomous question (1: yes; 0 : no). The majority showed that they do not have a business idea, nor have they ever had one $(62.9 \%)$ (see Table 10$)$. Oddly enough, the majority also showed that they have in fact thought at some

Table 8. Values of entrepreneurial self-perception, gender and nationality

\begin{tabular}{|l|c|c|c|}
\hline \multirow{2}{*}{ Enterprising } & Average & Variance & SD \\
\cline { 2 - 4 } & 6.57 & 2.36 & 1.56 \\
\hline Spanish & 6.61 & 2.50 & 1.62 \\
\hline Foreign & 6.50 & 2.08 & 1.51 \\
\hline Male & 6.58 & 2.08 & 1.51 \\
\hline Female & 6.57 & 2.51 & 1.62 \\
\hline
\end{tabular}

Table 9. Percentage distribution of entrepreneurial self-perception

\begin{tabular}{|l|c|c|c|c|c|}
\hline \multirow{2}{*}{ Enterprising } & Not at all & Not very & Normal & Quite & Completely \\
\cline { 2 - 6 } & $0.0 \%$ & $11.4 \%$ & $22.9 \%$ & $60.0 \%$ & $5.7 \%$ \\
\hline Spanish & $0.0 \%$ & $8.7 \%$ & $30.4 \%$ & $52.2 \%$ & $8.7 \%$ \\
\hline Foreign & $0.0 \%$ & $16.7 \%$ & $8.3 \%$ & $75.0 \%$ & $0.0 \%$ \\
\hline Male & $0.0 \%$ & $8.3 \%$ & $33.3 \%$ & $58.3 \%$ & $0.0 \%$ \\
\hline Female & $0.0 \%$ & $13.0 \%$ & $17.4 \%$ & $60.9 \%$ & $8.7 \%$ \\
\hline
\end{tabular}


Table 10. Percentage distribution by business idea

\begin{tabular}{|l|c|c|}
\hline \multirow{2}{*}{ Business idea } & Yes & No \\
\cline { 2 - 3 } & $37.1 \%$ & $62.9 \%$ \\
\hline Spanish & $30.4 \%$ & $69.6 \%$ \\
\hline Foreign & $50.0 \%$ & $50.0 \%$ \\
\hline Male & $58.3 \%$ & $41.7 \%$ \\
\hline Female & $26.1 \%$ & $73.9 \%$ \\
\hline
\end{tabular}

point about the possibility of creating their own company (88.6\%) (see Table 11). This means, surprisingly, that the majority of those who responded in the affirma- tive to this question $(58.1 \%)$ do not have a business idea nor have they ever had one.

In terms of the probability of creating their company within the (5) years to come, a closed question was formulated on a 5-point Likert scale (1: improbable; 5: very probable). The result is a neutral average value (see Table 12) although the distribution of the group by gender and nationality shows some interesting differences (see Table 13).

They were asked a 7-point Likert scale question (1: not at all; 7: completely) regarding whether the idea of creating their own company was considered attractive and its creation feasible. The result for "attractiveness of the idea of creating

Table 11. Percentage distribution by possibility of creating a business

\begin{tabular}{|l|c|c|}
\hline \multirow{2}{*}{\multicolumn{1}{c|}{ Possibility of creating }} & Yes & No \\
\cline { 2 - 3 } \cline { 2 - 3 } Spanish & $88.6 \%$ & $11.4 \%$ \\
\hline Foreign & $87.0 \%$ & $13.0 \%$ \\
\hline Male & $91.7 \%$ & $8.3 \%$ \\
\hline Female & $91.7 \%$ & $8.3 \%$ \\
\hline
\end{tabular}

Table 12. Values of the probability of starting their own business in the next 5 years

\begin{tabular}{|l|c|c|c|}
\hline \multirow{2}{*}{ Probability of starting in the next 5 years } & Average & Variance & SD \\
\cline { 2 - 4 } & 3.03 & 0.71 & 0.86 \\
\hline Spanish & 3.17 & 0.58 & 0.78 \\
\hline Foreign & 2.75 & 0.85 & 0.97 \\
\hline Male & 3.03 & 0.71 & 0.86 \\
\hline Female & 2.78 & 0.42 & 0.67 \\
\hline
\end{tabular}

Table 13. Percentage distribution of the probability of starting their own business in the next 5 years

\begin{tabular}{|l|c|r|r|r|c|}
\hline \multirow{2}{*}{$\begin{array}{l}\text { Probability of starting } \\
\text { in the next 5 years }\end{array}$} & Very unlikely & Unlikely & Neutral & Likely & Very likely \\
\cline { 2 - 6 } & $5.7 \%$ & $14.3 \%$ & $54.3 \%$ & $22.9 \%$ & $2.9 \%$ \\
\hline Spanish & $4.3 \%$ & $4.3 \%$ & $65.2 \%$ & $21.7 \%$ & $4.3 \%$ \\
\hline Foreign & $8.3 \%$ & $33.3 \%$ & $33.3 \%$ & $25.0 \%$ & $0.0 \%$ \\
\hline Male & $0.0 \%$ & $0.0 \%$ & $58.3 \%$ & $33.3 \%$ & $8.3 \%$ \\
\hline Female & $8.7 \%$ & $21.7 \%$ & $52.2 \%$ & $17.4 \%$ & $0.0 \%$ \\
\hline
\end{tabular}


your own company" had an average value of 5.91 out of 7 (see Table 14). However, the distribution by gender and nationality groups shows some interesting differences (see Table 15). The result for "feasibility of creating your own company" had an average value of 4.40 out of 7 (see Table 16). Likewise, the distribution by gender and nationality groups was unequal and interesting (see Table 17).

Table 14. Values of attractiveness of the idea of having their own business

\begin{tabular}{|l|c|c|c|}
\hline \multirow{2}{*}{ Attractiveness of the idea } & Average & Variance & SD \\
\cline { 2 - 4 } & 5.91 & 1.62 & 1.29 \\
\hline Spanish & 5.91 & 1.64 & 1.31 \\
\hline Foreign & 5.92 & 1.58 & 1.31 \\
\hline Male & 6.08 & 1.24 & 1.16 \\
\hline Female & 5.83 & 1.80 & 1.37 \\
\hline
\end{tabular}

Table 15. Percentage distribution of attractiveness of the idea of creating their business

\begin{tabular}{|l|c|c|c|c|c|}
\hline \multirow{2}{*}{$\begin{array}{c}\text { Attractiveness of the } \\
\text { idea }\end{array}$} & Not at all & Not very & Normal & Quite & Completely \\
\cline { 2 - 6 } & $0.0 \%$ & $2.9 \%$ & $14.3 \%$ & $37.1 \%$ & $45.7 \%$ \\
\hline Spanish & $0.0 \%$ & $4.3 \%$ & $8.7 \%$ & $43.5 \%$ & $43.5 \%$ \\
\hline Foreign & $0.0 \%$ & $0.0 \%$ & $25.0 \%$ & $25.0 \%$ & $50.0 \%$ \\
\hline Male & $0.0 \%$ & $0.0 \%$ & $16.7 \%$ & $33.3 \%$ & $50.0 \%$ \\
\hline Female & $0.0 \%$ & $4.3 \%$ & $13.0 \%$ & $39.1 \%$ & $43.5 \%$ \\
\hline
\end{tabular}

Table 16. Values of feasibility of creating their own business

\begin{tabular}{|l|c|c|c|}
\hline \multirow{2}{*}{$\begin{array}{c}\text { Feasibility of creating your own } \\
\text { business }\end{array}$} & Average & Variance & SD \\
\cline { 2 - 4 } & 4.40 & 2.35 & 1.56 \\
\hline Spanish & 4.61 & 1.89 & 1.41 \\
\hline Foreign & 4.00 & 3.00 & 1.81 \\
\hline Male & 5.00 & 2.33 & 1.60 \\
\hline Female & 4.09 & 2.08 & 1.47 \\
\hline
\end{tabular}

Table 17. Percentage distribution by feasibility of creating your business

\begin{tabular}{|l|c|c|c|c|c|}
\hline \multirow{2}{*}{$\begin{array}{c}\text { Feasibility of creating } \\
\text { your own business }\end{array}$} & Not at all & Not very & Normal & Quite & Completely \\
\cline { 2 - 5 } & $5.7 \%$ & $14.3 \%$ & $31.4 \%$ & $40.0 \%$ & $8.6 \%$ \\
\hline Spanish & $4.3 \%$ & $8.7 \%$ & $30.4 \%$ & $47.8 \%$ & $8.7 \%$ \\
\hline Foreign & $8.3 \%$ & $25.0 \%$ & $33.3 \%$ & $25.0 \%$ & $8.3 \%$ \\
\hline Male & $0.0 \%$ & $8.3 \%$ & $41.7 \%$ & $25.0 \%$ & $25.0 \%$ \\
\hline Female & $8.7 \%$ & $17.4 \%$ & $26.1 \%$ & $47.8 \%$ & $0.0 \%$ \\
\hline
\end{tabular}


Table 18. Values of the risk of creating a business

\begin{tabular}{|l|c|c|c|}
\hline \multirow{2}{*}{ Risk of creating a business } & Average & Variance & SD \\
\cline { 2 - 4 } & 7.23 & 1.49 & 1.24 \\
\hline Spanish & 7.00 & 1.48 & 1.24 \\
\hline Foreign & 7.67 & 1.22 & 1.15 \\
\hline Male & 7.58 & 0.91 & 1.00 \\
\hline Female & 7.04 & 1.69 & 1.33 \\
\hline
\end{tabular}

Table 19. Percentage distribution of riskiness of creating a business

\begin{tabular}{|l|c|c|c|c|c|}
\hline \multirow{2}{*}{ Risk of creating a business } & Not at all & Not very & Normal & Quite & Completely \\
\cline { 2 - 6 } & $0.0 \%$ & $0.0 \%$ & $28.6 \%$ & $57.1 \%$ & $14.3 \%$ \\
\hline Spanish & $0.0 \%$ & $0.0 \%$ & $39.1 \%$ & $52.2 \%$ & $8.7 \%$ \\
\hline Foreign & $0.0 \%$ & $0.0 \%$ & $8.3 \%$ & $66.7 \%$ & $25.0 \%$ \\
\hline Male & $0.0 \%$ & $0.0 \%$ & $16.7 \%$ & $66.7 \%$ & $16.7 \%$ \\
\hline Female & $0.0 \%$ & $0.0 \%$ & $34.8 \%$ & $52.2 \%$ & $13.0 \%$ \\
\hline
\end{tabular}

Table 20. Values of "future career" by gender and nationality

\begin{tabular}{|l|c|c|c|c|c|}
\hline \multicolumn{1}{|c|}{ Items } & Total & Male & Female & Spanish & Foreign \\
\hline Large company & 2.80 & 2.67 & 2.87 & 2.57 & 3.25 \\
\hline SME & 2.89 & 2.92 & 2.87 & 2.87 & 2.92 \\
\hline Businessperson & 3.37 & 4.00 & 3.04 & 3.43 & 3.25 \\
\hline Self-employed & 3.00 & 3.33 & 2.83 & 3.43 & 2.17 \\
\hline Public employee & 2.14 & 2.58 & 1.91 & 2.3 & 1.83 \\
\hline
\end{tabular}

Concerning whether creating a company was seen as risky, they were asked a question on a 10-point Likert scale (1: not at all; 10: completely). The result is an average value of 7.23 out of 10 (see Table 18 ). Likewise, the distribution by gender and nationality groups shows interesting differences (see Table 19).

In terms of what they think their professional future will be, they were asked a multiple choice question on a 5-point Likert scale (1: very improbable; 5: very probable). The choices were: a) employed as a manager of a large company; b) employed as a manager of a small company; c) businessperson with employ- ees; d) self-employed without employees; e) employed in public administration. The average values obtained are shown in Table 20. Once again there are interesting differences depending on gender and nationality.

Regarding whether there was some close business reference in their family or social circles, the majority $(72.2 \%)$ confirm having a business reference in the family circle or knowing some kind of business reference in their social circle (see Table 21). Among those who confirm this (see Table 22), $60 \%$ admit belonging to a family that owns a business, with national students predominating in this group $(75 \%)$. 
Table 21. Percentage distribution of business reference in social environment

\begin{tabular}{|l|c|c|}
\hline \multirow{2}{*}{ Do you have your business reference? } & Yes & No \\
\cline { 2 - 3 } & $72.2 \%$ & $27.7 \%$ \\
\hline Spanish & $78.2 \%$ & $21.8 \%$ \\
\hline Foreign & $61.5 \%$ & $38.5 \%$ \\
\hline Male & $91.7 \%$ & $8.3 \%$ \\
\hline Female & $62.5 \%$ & $37.5 \%$ \\
\hline
\end{tabular}

Table 22. Percentage distribution by affirmative business reference

\begin{tabular}{|c|c|c|c|c|}
\hline \multirow{3}{*}{\multicolumn{3}{|c|}{$\begin{array}{l}\text { Yes, I have a business reference in my family or social } \\
\text { environment }\end{array}$}} & \multicolumn{2}{|c|}{ Gender } \\
\hline & & & \multirow{2}{*}{$\begin{array}{l}\text { Male } \\
42.3 \%\end{array}$} & \multirow{2}{*}{$\begin{array}{c}\text { Female } \\
57.7 \%\end{array}$} \\
\hline & & & & \\
\hline \multirow{2}{*}{ Nationality } & Spanish & $69.2 \%$ & $26.9 \%$ & $42.3 \%$ \\
\hline & Foreign & $30.8 \%$ & $15.4 \%$ & $15.4 \%$ \\
\hline
\end{tabular}

\section{Results}

\subsection{Grades}

The results obtained, in relation to individual tasks, indicate that $69.8 \%$ (349) of the total task load (10 per student) was handed in. Regarding voluntary exercises, $78.8 \%$ (197) of the total possible exercises (5 per student) were handed in. The average grades corresponding to this part were 3.2 out of 4 for individual exercises ( $40 \%$ of the course grade) and 0.8 out of 1 for voluntary exercises ( $10 \%$ of the course grade). By groups, the national students handed in $81.6 \%$ (253) of the total possible individual exercises, and $87.7 \%$ (136) of the total possible voluntary exercises. Their grades were 3.6 out of 4 for individual exercises and 0.8 out of 1 for voluntary exercises. The foreign students handed in $53.3 \%$ (96) of the total possible individual exercises, and $67.8 \%$ (61) of the total possible voluntary exercises. Their grades were 2.5 out of 4 for individual exercises and 0.6 out of 1 for voluntary exercises. Female students handed in $71.9 \%$ (230) of the total possible individual exercises, and $78.8 \%$ (126) of the total possible voluntary exercises. Their grades were 3.2 out of 4 for the individual exercises and 0.7 out of 1 for the voluntary exercises. Male students handed in $70.0 \%$ (119) of the total possible individual exercises, and $83.5 \%$ (71) of the total possible voluntary exercises. Their grades were 3.1 out of 4 for individual exercises and 0.8 out of 1 for voluntary exercises (see Table 23).

In terms of business plans, 15 groups were created and developed the same number of final projects. The average number of people per group was 3.4. Only one group of 5 members was created (formed by foreign students) and no student decided to make a business plan alone. Of the 15 groups, 7 consisted fully of female students, 4 of national students and 3 of foreign students. One group consisted of male students and 7 were mixed; 4 groups consisted of national students and 3 of foreign students. There was no group formed by national and foreign students. The average number of persons in the groups formed by national students was 3.2, while for those formed by foreign students, the average was 3.7.

The average number of pages per project, following the formal conditions of the document, was 36.6 pages. The average grade for the projects was 6.6 out of 10 for "originality of the idea, innovation, and strategy," representing $50 \%$ of the final project, and 5.8 out of 10 for "technical, economic, and social viability," representing the other $50 \%$ of the final project. Both grades together constitute $40 \%$ of the final grade for the course. The average grade for the projects presented by national students 
Table 23. Percentage distribution of average grades for individual tasks and voluntary exercises by gender and nationality

\begin{tabular}{|c|c|c|c|c|}
\hline \multirow{2}{*}{\multicolumn{3}{|c|}{ Individual Tasks }} & \multicolumn{2}{|c|}{ Gender } \\
\hline & & & male & female \\
\hline \multirow{2}{*}{ Nationality } & Spanish & $81.6 \%$ & $76.0 \%$ & $84.3 \%$ \\
\hline & Foreign & $53.3 \%$ & $61.4 \%$ & $48.2 \%$ \\
\hline \multirow{3}{*}{\multicolumn{3}{|c|}{$\begin{array}{l}\text { Average grades for individual tasks } \\
\text { (of } 4 \text { points) }\end{array}$}} & \multicolumn{2}{|c|}{ Gender } \\
\hline & & & male & female \\
\hline & & & 3.1 & 3.2 \\
\hline \multirow{2}{*}{ Nationality } & Spanish & 3.6 & 3.3 & 3.7 \\
\hline & Foreign & 2.5 & 2.7 & 2.4 \\
\hline \multirow{3}{*}{\multicolumn{3}{|c|}{ Voluntary exercises }} & \multicolumn{2}{|c|}{ Gender } \\
\hline & & & male & female \\
\hline & & & $83.5 \%$ & $78.8 \%$ \\
\hline \multirow{2}{*}{ Nationality } & Spanish & $87.7 \%$ & $84.0 \%$ & $89.5 \%$ \\
\hline & Foreign & $67.8 \%$ & $82.9 \%$ & $58.2 \%$ \\
\hline \multirow{3}{*}{\multicolumn{3}{|c|}{$\begin{array}{l}\text { Average grades for voluntary exercises } \\
\text { (of } 1 \text { point) }\end{array}$}} & \multicolumn{2}{|c|}{ Gender } \\
\hline & & & male & female \\
\hline & & & 0.8 & 0.7 \\
\hline \multirow{2}{*}{ Nationality } & Spanish & 0.8 & 0.8 & 0.8 \\
\hline & Foreign & 0.6 & 0.8 & 0.5 \\
\hline
\end{tabular}

was 6.7 out of 10 for "originality of the idea, innovation, and strategy" and 5.7 out of 10 for "technical, economic, and social viability." The projects received a total average grade of 6.2 out of 10 . The average grade for projects presented by foreign students was 6.4 out of 10 for "originality of the idea, innovation, and strategy" and 6 out of 10 for "technical, economic, and social viability."

The average grade for the class presentations of the projects was 7.7 out of 10 , representing $10 \%$ of the final grade for the course. The average grade for class presentations of the projects by groups formed by national students was 7.9, and 7.6 in the case of presentations by groups formed by foreign students. The average grade for the class presentations by female students was 7.5 and by male students 8.2 .

The average grade for the course was 6 out of 10: 6.4 for the national student groups and 5.5 in the case of the groups of foreign students. The average grade for the course in the case of female students was 6.3 , and 5.5 for male students. Grade distributions were $4.1 \%$ - "A", $57.1 \%$ - "B", $30.6 \%$ - "Passed", and 8.2\% - "absent."

\subsection{Student opinions}

once the face-to-face sessions had ended and in order to know student opinions on the new teaching methodology, we asked them to fill in a questionnaire developed on the basis of similar papers and experiences, used in the area of teaching innovation programs at the Faculty of Economics and Business at the Albacete Campus. The questionnaire consisted of 20 assessment Likert-style questions, worded in a positive sense. To avoid the middle answer effect, the scale was 1: not at all; 4: very. We were interested in knowing their opinions about four elements: the preparation of the learning activities, the new methodology, its usefulness for learning, and the cooperative work activity. We were basically interested in their assessment 
of group work as "knowing how to work with others" was one of the most novel elements. The results of the assessment for each of the 4 above-mentioned elements or categories of questions appear in Table 24.

Table 24. Values of preparation, methodology, usefulness and cooperative work

\begin{tabular}{|l|c|c|c|}
\hline \multicolumn{1}{|c|}{ Categories } & Average & Variance & SD \\
\hline $\begin{array}{l}\text { Preparation of the } \\
\text { activity }\end{array}$ & 2.55 & 0.28 & 0.53 \\
\hline New methodology & 2.78 & 0.39 & 0.63 \\
\hline $\begin{array}{l}\text { Usefulness for } \\
\text { learning }\end{array}$ & 3.06 & 0.65 & 0.80 \\
\hline $\begin{array}{l}\text { Cooperative work } \\
\text { activity }\end{array}$ & 3.38 & 0.69 & 0.83 \\
\hline
\end{tabular}

The distribution of answers for each category is presented in Table 25, where the concentration of answers in the assessments of "quite" and "very" was confirmed. Of the responses on the group work activity, $90.2 \%$ are favorable or very favorable. Of those related to the preparation of the activity, $52.6 \%$ are likewise positive or very positive, which also holds true for the new methodology ( $77.5 \%$ of the responses) and its usefulness for learning $(71.2 \%$ of the responses).

In terms of the overall assessment of the activity, an average value of 2.84 was obtained out of a maximum of 4 . The distribution of the assessments means that $70.5 \%$ of the responses were accumulated in the options of "quite" $(50.8 \%)$ and "very" (19.7\%), making the results very positive.
Lastly, we asked the students to assess the course using a simple questionnaire with answers on a 10-point Likert scale (1: minimum value; 10: maximum value). The overall assessment was 8.4 out of 10 "Usefulness of the course" stands out (8.8), as do "interest of the course" (8.6) the "professor" (8.6), and the "evaluation criteria" (8.4). They were also asked about the material used (7.8), the development of face-to-face classes (7.5), the Virtual Campus resource (7.3), the content (7.0) and the duration of the course (6.6). The collection of information concludes with 4 open-ended questions on what they liked the most, the least, what they would add and what they would omit. Regarding what they liked the most, $94.1 \%$ of the students responded: $37.5 \%$ indicated the dynamics of face-to-face classes, $15.6 \%$ indicated the usefulness of the course, $12.5 \%$ pointed out the talks with entrepreneurs and young businesspeople, $9.4 \%$ said that it was the group work, another $9.4 \%$ responded that it was the placements, and another $9.4 \%$ opted for the business plan. On what they liked least, $59.4 \%$ of the students responded: $57.9 \%$ mentioned an excessive number of practical exercises, $10.5 \%$ indicated the lack of a manual, another $10.5 \%$ pointed to the group work tutorials, and another $10.5 \%$ chose the business plan. In terms of what they would add, $67.7 \%$ of the students responded to the question: $30.4 \%$ indicated a desire to discover the procedures for creating a company, $26.2 \%$ wanted more talks with entrepreneurs and young businesspeople, $13.1 \%$ would prefer more seminars and visits to companies, $8.7 \%$ opted for more tools to verify the viability of the plan. Lastly, $38.2 \%$ of the students responded to the question of what they would omit: $69.2 \%$ mentioned reducing the number of individual exercises and $23.1 \%$ would reduce the number of voluntary exercises.

Table 25. Distribution of responses by category

\begin{tabular}{|l|c|c|c|c|}
\hline \multicolumn{1}{|c|}{ Categories } & Not at all & Not very & Quite & Very \\
\hline Preparation of the activity & $2.11 \%$ & $45.26 \%$ & $45.26 \%$ & $7.37 \%$ \\
\hline New methodology & $5.63 \%$ & $16.88 \%$ & $53.75 \%$ & $23.75 \%$ \\
\hline Usefulness for learning & $1.25 \%$ & $27.50 \%$ & $50.00 \%$ & $21.25 \%$ \\
\hline Cooperative work activity & $4.88 \%$ & $4.88 \%$ & $58.54 \%$ & $31.71 \%$ \\
\hline
\end{tabular}

Wydział Zarządzania UW ～DOI 10.7172/1733-9758.2014.17.4 


\section{Conclusions}

The first outstanding element was the student profile. The fact of receiving noteworthy participation from foreign students allowed for greater and better dynamism in the classes, though improved relationships and integration between both groups should be achieved. On the other hand, the strong presence of female students allowed the application of research results in entrepreneurship and gender, for example, in activities related to the role of gender.

Regarding the entrepreneurial profile of the students, it would be interesting to measure the possible effect of the course on their entrepreneurial intent, rechecking some variables at the end of the semester. We hope to be able to present results in a subsequent study.

One challenge should be the generation of more truly innovative business ideas and moving forward some interesting projects, channeling them toward the various support services in the University itself or other institutions with entrepreneurial programs.

The activities that are carried out based on the new teaching methods (participative classes, self-learning, autonomous work, tutored work, group work, etc.) require greater involvement on the part of the students. Despite the fact that the graduate students have been trained in these methodologies, it seems advisable to strengthen some skills that should have been achieved in previous courses. It would be equally interesting to expressly control the achievement of certain skills.

An important element which does not depend exclusively on this course is the timing of all the tasks and exercises that the students have to do throughout the four months. Concentration of certain due dates when tasks and exercises from several courses coincide should be avoided.

One challenge to be overcome is to achieve greater effective interrelations with other courses and even interdisciplinary activities since there are contents related to the business plan (linked to Accounting and Finances, Marketing, Production and Operations, Human Resources, Commercial Law, Taxation, etc.) that could be treated jointly, and even evaluated on a cross-section basis.

Another element to be dealt with is the fact that in the final project for the degree, the possibility of it being a business plan is expressly considered, which opens up new possibilities and generates new problems that need to be solved.

The grades received by the students are acceptable although with the new methodologies it is more difficult to achieve better results individually since group work is introduced as a part of the final grade.

Analyzing the results of student opinions regarding the new methodology and the course as a whole, we see that the assessment of the course "Creation of Innovative Companies" is positive. The assessment of the professor is equally positive and very satisfactory. However, we feel it is advisable to compare methodologies and results with colleagues who teach similar courses and subjects in the Spanish university system so that we could exchange experiences that enable us to capture and apply the best practices achieved. Likewise, it could be useful to compare these experiences in the international setting.

\section{Notes}

1 "Oslo Agenda for Entrepreneurship Education in Europe": promotion of entrepreneurship among young Europeans and training and education in entrepreneurship, pursuing the goals of innovation, competitiveness, and growth, in line with the Lisbon 2000 strategy, as expressed in the document "Education and Training 2010" of the European Commission.

2 [Similar to a "Major" - Translator's note]. The "Mention" is similar to a recommended pathway, without expressly being a specialization. Its courses offer required contents and materials and its skills are complementary to gaining more specific training. But it is not compulsory to take the whole lot of the courses offered. A student can choose from among several subjects from different pathways. But only if those subjects are chosen which are given in the group, will the student be expressly awarded the "Title of Mention".

3 By agreement with the Faculty Council, it was decided to limit the number of students registered per all optional courses to 25 , in order to avoid the recorded imbalances in the Degree that before left other optional courses with few or no registrations (it had a consequent effect of their disappearance from the range of optional courses in later years and the decrease in the teaching load for the professors of those courses because at least 10 registered students are required to teach a course under the academic legal conditions of our University). The 
students choose optional courses during the registration process, in accordance with the established order, depending on their grades from the previous year. The courses that are filled first are principally those with students having the best record. In the case of this course, given the demand, the quota was extended again and, moreover, further foreign students joined later, also by choice, since there is the possibility of continuing the course by enrolling in English through the Virtual Campus (teaching guide, class and presentation material, lectures and cases, task documents, bibliography, group work, tutorials, sessions for Erasmus students, and the possibility to submit exercises in French, Italian, and Portuguese as well as in English).

\section{References}

Ajzen, I. (1991). The Theory of Planned Behaviour Organizational Behaviour and Human Decision Processes, 50, 179-211.

Bandura, A. (1997). Self-efficacy: The Exercise of Control. New York, NY: W.H. Freeman.

Diaz, M.C. and Jiménez, J.J. (2010). Entrepreneurial Intention: The Role of Gender. Internationa Entrepreneurship and Management Journal, 6(3), 261-283.

Díaz, M.C. and Jiménez, J.J. (2008). Factores que inciden en la intención empresarial: Propuesta de un modelo $[=$ Factors affecting entrepreneuria intention: Proposal of a model]. In: R. Hernández (ed.), Creación de Empresas: Aproximación al Estado del Arte. Curitiba (Brasil): Juruá Editora.

Jiménez, J.J. and Díaz, M.C. (2009). Evaluación del impacto de la asignatura 'Creación de Empresas' en la intención empresarial de su alumnado [=Assessing the impact of the 'Entrepreneurship' course on entrepreneurial intention of the students]. In A. Legato et al. (eds.), V Encuentro Regional de
Centros de Investigación en Administración y disciplinas afines. Tandil (Argentina): UNICEN.

Jimenez-Moreno, J.J. and Oliveras, G. (2012). Entrepreneurial Attitude of Young Female University Students: A Case Study. 57th ICSB World Conference, Small Enterprise Association of Australia and New Zealand.

Jimenez-Moreno, J.J., Oliveras, G. and RodenasFernandez, J.M. (2013). La intención emprendedora en estudiantes de educación secundaria y bachillerato: un estudio exploratorio previo a la aplicación de la 'Ley de Emprendedores' [=Entrepreneurial intention in secondary and pre-university students]. GLObal-loCAL Innovation \& Entrepreneurship. Lessons from a Diverse World.

Krueger, N. and Kickul, J. (2006). So You Thought the Intentions Model was Simple?: Navigating the Complexities and Interactions of Cognitive Style, Culture, Gender, Social Norms, and Intensity on the Pathways to Entrepreneurship. USASBE conference, Tuscon, AZ.

Krueger, N.F., Reilly, M.D. and Casrud, A.L. (2000). Competing models of entrepreneurial intentions. Journal of Business Venturing, 15, 411-432.

Liao, J. and Welsch, H. (2004). Entrepreneurial intensity. In: W.B. Gartner, K.G. Shaver, N.M. Carter and P.D. Reynolds (eds.), Handbook of Entrepreneurial Dynamics. Thousand Oaks, California: Sage Publications.

Ripolles, M., Martínez, L., Jiménez, J.J., Varamaki, E. and Joensuu, S. (2013). Entrepreneurial Intention Among Male and Female Undergraduate Students; The Role of Universities in Fostering Entrepreneurship. RENT Conference 2013.

Shapero, A. (1982). The social dimensions of entrepreneurship. In: C.A. Kent, D.L. Sexton and K. Vesper (eds.), The Encyclopaedia of Entrepreneurship (72-90). Englewood Cliffs, NJ: Prentice Hall. 